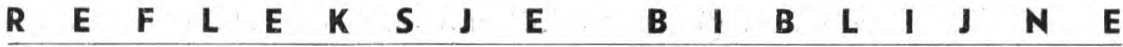

\section{GODZINA BIBLIJNA}

\section{DROGA KRZYZ̄OWA}

(Szkic na dwie godziny biblijne)

W czasie intronizacji Ewangęlii śpiewać można pieśń wielkopostną: „Rozmyślajmy dziś”.

\section{STACJA I.}

Czytamy w ewangelii św. Jana 19, 4-16: Wyszed $i$ Pilat i rzekł do tlumu zebranego. - Oto wyprowadzam do was Jezusa, abyście zrozumieli, że nie znajduję $w$ Nim winy. Gdy wyszedt Jezus ubrany $w$ cierniowa korone $i$ płaszcz purpurowy, rzekł im Piłat: Patrzcie, jaki to 'człowiek! Gdy Go tak ujrzeli najwyżsi kapłani $i$ ich słudzy krzyczeli: ukrzyżuj Go, ukrzyżuj Go! A Piłat oświadczył: Weźcie wy Go sobie $i$ ukrzyżujcie, bo ja w Nim nie znajduję żadnej winy. Odpowiedzieli mu ̇̇ydzi: my mamy swoje prawo $i$ wedlug tego prawa musi umrzeć, ponieważ Synem Bȯ̇ym się ogłaszał.

A byt to dzień przygotowania paschy, dochodziła godzina szósta. I jeszcze raz odezwał się Piłat do Żydów: Patrzcie, to król wasz! A oni krzyczeli: precz z Nim. Ukrzyżuj Go! A rzekł im Piłat: Króla waszego mam ukrzyżować? A najwyżsi kapłani odpowiedzieli: Nie mamy króla poza cesarzem. Teraz oto wydat Go im, aby byt ukrzyżowany.

Gdy rozważamy wyrok wydany przez rzymskiego prokuratora, wyrok niczym nie uzasadniony przez prawo rzymskie, stanowiący samowolę Piłata i złą wolę hierarchii jerozolimskiej, którą popierało kilkudziesięciu przez nią najętych ludzi z ulicy, zdajemy sobie sprawę, że taka była wo̊la Ojca Niebieskiego. Chciał tego Bóg Odwieczny, by Jego Syn wziął na siebie winy całego świata i całej ludzkości od jej zaistnienia na ziemi i zginął jako Baranek niewinny, jako ofiara złożona Sprawiedliwości Bożej.

A Chrystus milcząco wyrok przyjmuje i powtarza słowa modlitwy wypowiedzianej w Ogrojcu: „Smutna jest dusza moja aż do śmierci... ciało moje słabe, ale duch jest chętny... Ojcze Niebieski, niech się dzieje wola Twoja!" 
Chwilę tę odmalowuje trafnymi słowami św. Piotr w swym I. liście kiedy pisze $(2,21)$ : „Chrystus cierpiał za was i przykład wam zostawił, abyście wstępowali w jego ślady. Gdy mu złorzeczono, nie złorzeczył, gdy cierpiał, nie odgrażał się lecz poddał temu, który sądził według prawa. Na ciele swoim mając grzechy nasze, niósł je na drzewo krzyża, abyśmy wszyscy umarli dla grzechów a żyli dla sprawiedliwości".

\section{STACJA II.}

Krótko wspominają ewangeliści o rozpoczęciu drogi krzyżowej: „Wtedy żołnierze Namiestnika zdjęli z Jezusa płaszcz purpurowy, ubrali Go w Jego szaty i wyprowadzili na ukrzyżowanie (Mat 27, 31).

$\mathrm{Z}$ chwilą, w której Pan Jezus wziął krzyż na swe ramię, drzewo krzyża przez dotyk Jego rąk zostało uświęcone i z symbolu największej hańby zamienione na znak zbawienia. Sam Jezus wspomniał w ewangelii św. Jana, że obrazem krzyża jest wąż zawieszony przez Mojżesza na żerdzi, by leczyć wszystkich ukąszonych przez żmije na pustyni. Tak samo leczy świat drzewo krzyża świętego, na którym zawisł Syn Boży i które dźwigał na zranionych przez biczowanie plecach z pretorium Piłata aż na miejsce kaźni.

Oto co pisze św. Jan: Jak Mojżesz zawiesił wysoko węża na pustyni, tak trzeba, aby zawisł wysoko Syn Człowieczy, ażeby każdy, który weń uwierzy, uzyskał życie wieczne $(3,14)$.

Zapewne cisnęły się Jezusowi do ust słowa psalmisty: „Ofiar i darów nie chciałeś, w całopaleniach nie masz upodobania, dlatego rzekłem: Oto idę aby pełnić wolę Twoją, Boże $(39,8)$.

Krew wylewana na oltarzu, krew zwierzat nierozumnych, nie mogła oczyszczać ludzi z grzechu, ale była obrazem owej krwi, którą Chrystus miał przelać na krzyżu, i jako obraz miała w sobie siłę wychowawczą, by człowiekowi przypominać zło, jakie w każdym grzechu tkwi, i go nakłonić do aktów szczerego żalu.

A widząc okiem wyobraźni Pana Jezusa biorącego krzyż na swe ramiona, przypominamy sobie Jego słowa:

Kto chce pójść za mna, niech zaprze się samego siebie, niech bierze codziennie krzyż swój na siebie i niech naśladuje mnie (Euk. 9, 23).

Kto nie dźwiga krzyża swego $i$ nie idzie za mna, nie może być uczniem moim (Euk. 14, 27).

Kto nie bierze na siebie krzyża swego $i$ nie naśladuje mnie nie jest mnie godzien (Mat. 10, 38).

Słuszna jest uwaga św. Pawła: Nauka o krzyżu jest dla tych, którzy ida na zatracenie, głupstwem a dla nas oczekujacych zbawienia jest potęga Boża (Kor. 2, 18). 


\section{STACJA III.}

O upadkach Pana Jezusa pod ciężarem krzyża nie wspominają ewangeliści, ale tradycja o tym mówi, tradycja uzasadniona. Na bruku nierównym ulic jerozolimskich, wśród tłoku. ogromnego na ciasnej via dolorosa, przy siłach wyczerpanych nocną udręką potknął się Jezus kilka razy.

W czasie drogi krzyżowej przypomniał sobie zapewne psalm 142, gdzie znajdują się słowa smutne, ale prawdziwe:

Wróg prżeśladuje mnie, $w$ proch już stracil me $\dot{z} y c i e . .$.

Serce we mnie się ściska

a ja rozważam rak Twych działanie, o Boże!

Ku Tobie ręce wyciagam,

ukaż mi drogę, która iść winienem,

do Ciebie się uciekam,

naucz mnie czynić wole Twoja

boś Ty mój Bóg!

Jakże inaczej w Wielki Piątek brzmiały te słowa w ustach Chrystusa prowadzonego na Golgotę! Mógł jeszcze dodać do swej niemej modlitwy wiersz z psalmu 31:

Milczę a kości me słabna, gdyż Twoja ręka, Boże, na mnie zaciężyła!

Widząc Jezusa leżącego w prochu ullicy, stwierdzamy, że spełnia się wizja opisana przez Izajasza proroka:

Głowa cała chora, serce całkiem mdłe. Od stóp aż do głowy nie ma na nim miejsca zdrowego, same rany $i$ wrzody $i$ since a nie sa wyciśnione ani zaopatrzone ani oliwa zalane $(1,6)$.

„Nie ma w nim ani kształtu ani piękności, wzgardzony on, przez ludzi, opuszczony, mąż boleści - vir dolorum - a on naprawdę nosi na sobie słabości nåsze, wziął na siebie nasze boleści (Iz 53, 2).

\section{STACJA IV.}

Spełniają się w tej chwili słowa starca Symeona, który w świątyni jerozolimskiej powiedzial do Matki Najświętszej wskazując na dzieciątko na jej rękach: ,(Syn twój) przeznaczony jest na znak, któremu sprzeciwiać się będą, a twoją duszę miecz przeszyje" (Euk. 2, 35).

Ostrze miecza przenika duszę Marii, gdy patrzy na Jezusa, przed 5 dniami uwielbianego jeszcze przez tłumy a teraz poniewieranego okrutnie przez setki czy nawet tysiące swoich braci. W rzewnych modlitwach wypowiada Maria swe żale: Spojrzyj, Panie, na cierpienie moje! A wy wszyscy, którzy droga idziecie, patrzcie i spogla- 
dajcie, czy jest boleść jako boleść moja. Gorzko płakać muszę, me oko we izach sie rozpływa. A jakże daleki ode mnie pocieszyciel, któryby mnie pokrzepit".

Modlitwę tę ułożył kiedyś prorok pogrążony w smutku po zburzeniu Jeruzalem, a my idąc za myślami tego proroka odzywamy się do Marii: Jakże cię pocieszę? Do kogo cię przyrównam, o Dziewico, o córko Syjonu? Bo wielkie jak morze jest przygnębienie twoje (Sam. 1, 12).

Współczując z Marią naśladujmy jej postawę duchową. Widzi bliską już śmierć Jezusa, czuje, że wszyscy mieszkańcy Stolicy sa przekonani o upadku misji Chrystusowej, ale wiary nie traci i wierzy, że jej Syn nauką swoją cały świat zwycięży, pomna słów smutnych a mocnych, które Jezus przed kilku godzinami wypowiedział w Wiećzerniku: „Ọto nadchodzi godzina i już nadeszła, że rozpierzchniecie się każdy do swoich a mnie zostawicie samego... na świecie ucisk mieć będziecie, ale ufajcie, jam zwyciężył świat" (Jan 16, 32).

Prośmy Boga przez Marię o równie silną wiarę, aby Chrystus dzięki wierze naszej zamieszkat $w$ sercach naszych, jak upomina św. Paweł (Ef 3, 17).

\section{STACJA V.}

Czytamy w ewangelii św. Łukasza: „A gdy prowadzili Jezusa na Golgotę, przytrzymali niejakiego Szymona z Cyrene, który z pola wracał, i włożyli na niego krzyż, aby go niósł za Jezusem" $(23,26)$.

Krótka to tylko wiadomość, ale bardzo znamienna. Nic bliższego nam o Szymonie nie przekazano, tylko tyle, że pochodził z Cyrene, z kolonii położonej w północnenj Afryce, ale jest to szczegół ważny. Dzięki swemu pochodzeniu $z$ tzw. diaspory, Szymon stał się reprezentantem synów Izraela mieszkających poza Palestyną i jakoby w imieniu swych współbraci na obczyźnie towarzyszy Chrystusowi w drodze na miejsce stracenia, by zapewnić zbawienie sobie i Żydom żyjącym w rozproszeniu po całym państwie rzymskim.

Ale przykre jest dla nas wspomnienie, i nie całkiem zrozumiałe, że najbliżsi towarzysze Jezusa, z którymi tak serdecznie się rozstał w Wieczerniku, prawie wszyscy Go opuścili a nikt z nich nie spieszył $\mathrm{Mu} \mathrm{z}$ pomoca. Tak ogromna była ich konsternacja, tak wielki lęk przed aresztowaniem, tak słaba wiara w ich Mistrza, że wiekopomny zaszczyt niesienia krzyża odstępują człowiekowi obcemu. Zapewne ze łzami napisał św. Mateusz te słowa: Uczniowie wszyscy opuścili Go i pouciekali $(26,56)$. Uważali Go jakby za trędowatego, przed którym ludzie uciekają, jak o tym pisze Izajasz $(35,4)$. Miało się $\mathrm{w}$ ten sposób spełnić proroctwo Zachariasza: Uderz pasterza a owce sie rozprosza $(13,7)$, zastosowane do siebie przez Pana Jezusa, gdy szedl z Apostołami po wieczerzy na Górę Oliwną. 
Lecz nie dlugo trwało ich zwątpienie, gdyż modlił się za nich Chrystus, jak o tym zapewnił Piotra: A ja modlitem się za ciebie, aby nie ustała wiara twoja (Euk 22, 32). Już za kilka dni odzyskali równowagę, a za miesiąc mieli otrzymać jakoby sakrament bierzmowania, moc $i$ łaskę Ducha świętego. A wówczas już przejęci do głębi swym urzędem apostolskim modlili się wraz z Pawłem z Tarsu, który jak Szymon pochodził z diaspory: Nie daj, o Boże, abym się chlubit, czym innym aniżeli krzyżem Pana naszego Jezusa Chrystusa. Przez niego jest dla mnie świat ukrzyżowany a ja dla świata (Gal 6, 14).

Obym i ja tę myśl zrozumiał i czuł się ukrzyżowanym dla šwiata, to znaczy, bym umiał krzyż swój nosić i iść za Chrystusem i stronić od grzechów świata, bym przykładem wiary, miłości i umartwienia pozyskał innych dla Niego, tych, „którzy są nieprzyjaciółmi krzyża Chrystusowego, których bogiem jest brzuch, chlubą sprosności a troską rzeczy ziemskie" (Fil 3, 18).

\section{STACJA VI.}

Jest to obraz przejęty $\mathrm{z}$ misteriów średniowiecznych, kiedy to w kościele lub przed kościo.łem dawano przedstawienia pasyjne, oddające dobrze uczucia, jakie poruszały serca kobiet towárzyszących Jezusowi w Jego ostatniej drodze. Wspomina o nich św. Łukasz, pisząc $(23,27)$ : „I szła za nim wielka rzesza ludu i niewiast, które płakały i ubolewały nad nim". Było to porywem miłości bliźniego, porywem naturalnym dobrego serca niewieściego, że jedna $z$ nich przystąpiła do Jezusa, by chustą otrzeć Jego twarz, okrytą potem, krwią i prochem. A imię, jakie dała legenda litościwej kobiecie, brzmiało Berenike (Ferenike). Oznaczało ono osebę przynoszącą zwycięstwo i jest pochodzenia greckiego, z czego wynika, że według tradycji pochodziła z otoczenia nie-palestyńskiego, że była tak samo, jak Szymon, przedstawicielką diaspory żydowskiej. Tym sposobem podkreślono fakt, że ludzie obcy, obeznani ze światem pogańskim lub zeń pochodzący, bliżsi byli Chrystusowi aniżeli Jego rodacy palestyńscy i tutaj poznajemy prawdę słów Chrystusowych zawartych w przypowieści o dzierżawcach winnicy: Od was (potomkowie rodu Jakuba) odjęte będzie królestwo Boże $i$ oddane narodowi oddajacemu plony królestwu. Antiocha i Rzym miały w przyszłości zająć miejsce Jerozolimy (Mat 21, 43).

Berenike-Weronika wnikała instynktem kobiety w nastrój duszy Chrystusowej. Zdawało jej się, że Chrystus cicho powtarza sobie. słowa proroka Micheasza $(6,3)$ : „Ludu mój, cóż ci uczyniłem, czym zasmuciłem Ciebie? Odpowiedz mi! Z Egiptu cię wyprowadziłem, wybawiłem z domu niewoli" i dodaje do nich zakończenie: a tyś zgotował krzyż Zbawicielowi swemu! Zdawało jej się, -że Chrystus modli się z psalmistą: „Tak mi za dobre złem odpłacają i nastają 
na życie moje" (34, 12); „Stałem się jakby dzbanem rozbitym... ucieka przede mną, kto mnie ujrzy na drodze" $(30,12)$. Pełna litości i miłości do Chrystusa przystąpiła do Niego, nam przykład dając, by przywiązanie nasze do Zbawiciela było równie silne a połączone z gotowością ulżenia $\mathrm{Mu}$ w Jego cierpieniach.

A stale ulgę przynosi Chrystusowi kto ją sprawia bliźniemu. Wszakże powiedział Pan Jezus: „Zaprawdę powiadam wam, cokolwiek uczyniliście jednemu $\mathrm{z}$ braci moich najmniejszych, mnieście uczynili" (Mat 25, 40); ktokolwiek dałby komuś najmniejszemu chociażby kubek zimnej wody, zaprawde powiadam wam, nie straci zapłaty swojej (Mat 10, 42).

Czyż kobieta, która Panu Jezusowi obmyła oblicze, która jest symbolem chrześcijanki wspomagającej Chrystusa w bliźnich, otrzymała swą zapłatę? Odnosi się do niej obietnica Boskiego Mistrza, wypowiedziana w mowie pożegnalnej przed Wielkim Piątkiem: Kto mnie miłuje, tego miłuje Ojciec mój $i$ ja go miłować będę $i$ objawie mu siebie samego (Jan 14,21). Może twórcy opowiadania o św. Weronice o tym właśnie wierszu $\mathrm{z}$ ewangelii św. Jana myśleli gdy swój utwór spisywali. Wierzyli, że Chrystus jej się objawił, że ona obecność Jego w swej duszy odczuła, a symbolem tej obecności mistycznej Pana Jezusa było dla nich odbicie oblicza Najdroższego na „chuście Weroniki”.

\section{STACJA VII.}

Modlitwa nie schodzi z ust Chrystusa. Modli się zapewne tak, jak modlił się psalmista $(38,10)$ :

Uczyniłeś mnie Panie, pośmiewiskiem bezb̉oznych, a ja milczę $i$ ust nie otwieram, boś Ty to sprawit, o Boże.

Ach odwróć Twe ciosy ode mnie, gdyż maleje pod razami cięzkiej ręki Twojej...

i upada mdlejąc pod ciężarem czarnych myśli, jakie owładnęły Jego duszę, gdyż widzi jako Bóg wszechwiedzący milionowe rzesze, które nie wezmą na siebie jarzma Chrystusowego. Nie krzyż Go przygniata - przecież dźwiga go Szymon z Cyrene - ale smutek gł̨̨boki, że nie wszystkich zbawić potrafi.

Upadki Pana Jezusa są nie tylko upadkami, potknięciami, ale równocześnie modlitwami skierowanymi do nieba, w których ofiaruje Bogu Ojcu swe cierpienia za zbawienie ludzkości, są jakoby powtórzeniem Jego modlitwy w Ogrójcu. Trzy razy odchodził Jezus od uczniów, trzy razy rzucał się na twarz, by w samotności zupełnej rozmawiać z Ojcem swoim i mu swą gotowość wyrazić wykonania dzieła mu zleconego przed wiekami. Trzy razy także - gdy słuchamy głosu tradycji - Jezus upada w czasie drogi krzyżowej. W czasie pierwszego upadku przygniata Go ciężar grzechów popeł- 
nionych od Adama aż do Abrahama, w czasie drugiego upadku cierpi za grzechy popełnione od Abrahama aż do Annasza i Kaifasza, a w czasie trzeciego upadku przeprasza Boga Ojca za grzechy, jakie świat chrześcijański popełniać będzie od pierwszego Piotra, syna Jonasza, aż do drugiego Piotra przy końcu świata.

Zlituj się nad ludem twoim, nad którym wezwane jest imię twoje, zlituj się nad świętym miastem twoim (Syr 36, 14).

szepcą usta Syna Bożego w odpowiedzi na krzyki, jakie dochodzą do uszu Jego i które żądają przyspieszenia Jego stracenia.

Krótko trwa omdlenie Jezusa. Już się zrywa i dalej kroczy ku górze Golgota do "oltarza swego" - z tym samym uczuciem, z jakim przed 1700 laty wspinał się tutaj na sąsiednią górę Morian patriarcha Abraham, zdecydowany posłuchać rozkazu Boga, który doń rzekł: „Weź syna twego jedynego, którego kochasz, idź do krainy Moriah i ofiaruj go tam na jednej z gór, którą ci wskażę, na całopalenie" (Gen 22, 2). Posłuszny był Abraham Bogu a posłuszny był i Chrystus Ojcu swojemu, gdyż nie tylko z własnej woli i inicjatywy dźwiga krzyż, ale i z posłuszeństwa wobec Boga-Ojca, jak to zaznacza św. Paweł, że Chrystus ,stał się posłusznym aż do śmierci, aż do śmierci krzyżowej" (Fil 2, 5).

\section{STACJA VIII.}

Swiętemu Eukaszowi zawdzięczamy opis tej sceny. Pisze on (23, 27). I sża za Jezusem wielka rzesza ludu i kobiet, które go żatowaty i opłakiwały. Obrócił się do nich Jezus i rzekt: Córki jerózolimskie, nie płaczcie nade mna, lecz płaczcie same nad soba $i$ nad dziećmi swoimi. Bo przyjda oto dni, w których mówić się będzie: szczęśliwe matki bezdzietne... A zaczna .potem ludzie wolać do gór: padnijcie na nas a do pagórków. przykryjcie nas. Ozeasz 10, 3). Otóż jeżeli to z zielonym drzewem się dzieje, cóż z suchym się staniø?

Słowa te są dowodem, że Pan Jezus pomimo wielkiego wyczerpania i upadku sił fizycznych nie stracił przytomności umysłu. $\mathrm{Pa}$ nuje nad sytuacją, przypomina sobie przepowiednię proroka Ozeasza i wplata ją do słów pocieszenia. Piękno i majestat jego duszy występuje tu w całej pełni. Zapomina o sobie, nie myśli o katuszach, jakie znosić musi, lecz boleje tylko nad niedolą Jerozolimy i rodzin żydowskich. Używając znanego wówczas przysłowia o drzewie zielonym i suchym, przyrównuje siebie do drzewa zielonego, okrytego liśćmi i kwiatami, pełnego soków żywotnych, i stwierdza, że jego cierpienie, jakkolwiek ciężkie i poniżające, jest lżejszym od udręki, jaką kiedyś przechodzić będzie gród jerozolimski, który już teraz jest niejako drzewem suchym, bez życia, którego mieszkańcy nie rozumieją przedziwnych dróg Bożych. A jakiż to wspaniały rys 
w jego zachowaniu się, że szczególnie współczuje z matkami i dziećmi i ku nim kieruje słowa pociechy!

Miał Boski Zbawiciel serce bardzo czułe, co szczególnie podkreśla św. Łukasz, lekarz i psycholog. Dwukrotnie wspomina ewangelia o płaczu Pana Jezusa: plakał nad Jerozolimą (Łuk 19, 41) i płakał nad grobem Eazarza (Jan 11, 35), dwukrotnie wyszły $z$ ust Jezusa słowa: ,nie płacz, nie płaczcie”, raz gdy pociesza wdowę w Naim (Euk 7,13 ) a drugi raz, gdy pociesza rodzinę Jaira, któremu umarła córeczka. A po raz trzeci kieruje słowa: „nie płaczcie” do kobiet, które uwierzyły w jego posłannictwo i mu towarzyszyły w najboleśniejszej chwili jego życia.

Jak w czasie niewoli babilońskiej Jahwe pocieszał wysiedleńców przypominając im: Ja, ja jestem pocieszeniem waszym (Iz 51, 12), tak samo Pan Jezus wlewał otuchę w serca rzesz, wołając Przyjdźcie do mnie wszyscy utrudzeni i obciażeni troskami a odpoczynek u mnie zrajdziecie (Mat 11, 28). Myśl Chrystusową szerzej rozwija św. Paweł w II liście do Koryntian $(1,3)$ : ...(Pan) jest Ojcem miłosierdzia i Bogiem wszelkiego pocieszenia, który nas pociesza $w$ każdym utrapieniu naszym, abyśmy sami i innych pocieszać umieli, którzy maja jakiekolwiek strapienie pocieszać; takim pokrzepieniem, jakim nas samych Bóg pokrzepit.

Stąd płynie upomnienie dla wszystkich chrześcijan, byśmy nie tylko myśleli o pcmocy materialnej dla potrzebujących, ale przede wszystkim o podtrzymywaniu bliźnich na duchu i o pocieszaniu ich w chwilach smutku i rozpaczy. Pamiętajmy o uczynkach miłosiernych co do duszy, na które tak rzadko zwracamy uwagę w naszych stosunkach z innymi osobami, a które stanowią istotną część etyki ewangelicznej.

STACJA IX.

Nie orszak żałobny, milczący idzie ulicami stolicy, lecz tłum rozkrzyczany, żądny widowiska krwawego, pcha naprzód "zołnierzy prowadzacych Jezusa i wskutek tłoku, jaki powstał przy wyjściu z miasta, zachwiały się ponownie nogi Zbawiciela i runą na ziemiẹ. Upada tutaj, u stóp góry stracenia, po raz trzeci i rozkładia ramiona, by się na nich oprzeć i zmniejszyć ból upadku. Pisze prorok w Trenach Bibliinych $(1,17)$, że „Syjon rozkłada ramiona”. A tutaj Zbawiciel świata je rozkłada, jakoby krzyżem leży na skalistej drodze, by wymodlić łaskę wiary dla swoich oprawców a łaskę wytrwałości dla uczniów i przyjaciół.

Czuje Pan Jezus, jak wielkie jest podobieństwo między jego położeniem a losem Jerozolimy zajętej przez wojska babilońskie, opisanym przez autora biblijnego. Mógł i 'Pan Jezus o sobie powiedzieć (Lam 1, 13): 
Z wysokości ogień (Pan) zesłat,

spuścił go w kości moje.,

grzechy (wszystkie) czuwaja przy mnie,

razem zebrane $w$ Jego ręce,

leża na karku moim,

zachwiała sie siła moja.

Pan oddat mnie $w$ ich ręce,

ju̇̇ podnieść się nie mogę.

Jeszcze wyraźniej opisuje nam cierpienie i omdlenie Jezusa psalm 21, przez najdawniejszą tradycję uważany za przepowiednię męki Chrystusowej. Stanowi on modlitwę, którą Pan Jezus odmawiał w czasie drogi krzyżowej, w chwili upadku i ukrzyżowania!

A ja robakiem jestem, nie człowiekiem - modli się Jezus, wstrętem dla ludzi i wzgarda pospólstwa.

Rozsprzęgły się we mnie kości moje,

wyschła jak czerep siła moja

a język uwiazł mi w gardle,

ach, straciłeś mnie $w$ śmierci proch.

My zaś wpatrując się $w$ Jezusa leżącego na ziemi, ciśniętego $w$ proch śmierci wyznajemy razem $z$ św. Janem Chrzcicielem (Jan 1, 29): Oto Baranek Boży, oto który gładzi grzech świata" a razem $z$ trędowatym wołamy: "Jezusie, zmiłuj się nad nami" (Ek 17, 13). Przecież „myśmy wszyscy grzeszyli”, jak słusznie mówi św. Paweł (Rzym 3, 23), i nadal błądzimy i grzeszymy i błagamy Boga o milosierdzie" przez Chrystusa Pana naszego" (Rzym 7, 25).

\section{STACJA X.}

Już pochód jest na szczycie góry Golgota! Oto słowa św. Mateusza $(27,33)$ : I przyszli na miejsce, zwane Golgota, to znaczy: miejsce trupiej głowy. I dali mu pić wino zmieszane z żółcią, a gdy skosztował, nie chciał pić". Inne szczegóły podaje św. Jan $(19,23)$ pisząc: Waięli żolnierze jego szaty $i$ podzielili je na cztery części, dla każdego żolnierza po jednej, a zabrali takize suknię jego, która byla bez szwa, od góry tkana w całości. Dlatego mówili jeden do drugiego: Nie krajmy jej, ale losujmy o nia, czyja ma być. Tak spetnito się stowo Pisma (świętego): podzielili sobie szaty moje a o suknię moja los rzucili.

Bez protesu poddaje się Pan Jezus egzekucji. Modli się. Czy dobiera własne słowa do swej modlitwy, czy też bierze je z pieśni ukochanych przez jego naród, z księgi psalmów? Przypuszczać nam wolno, że jako Bóg wszechwiedzący, dla którego czas przeszły i przyszły równa się teraźniejszemu, widział najwyraźniej, jak słowa Ruch Biblijny i Liturgiczny - II 
przed wiekami spisane przez inspirowanych autorów spełniają się na nim w tej właśnie chwili. Z tej racji dalej przypuszczać nam wolno, że do swych modlów wplata myśli zawarte w psalmach i żali się do Boga (ps 68, 18 i 87, 15):

Ty, Boże, wiesz, jak mnie hańbia, jak znieważaja mnie, jak ze mnie szydza.

Nędzę i shańbienie widzi me serce przed soba.

Czekam, by współczuł ktoś ze mna a nie ma nikogo,

by ktoś mnie pocieszyt, a nikt się nie znalazt.

Żótć na pokarm mi daja

a $w$ mym pragnieniu octem mnie poja".

„Już zaliczono mnie do ludzi $w$ otchłań schodzacych,

jestem jakoby mara-człowiekiem

$i$ jak umarli wyzuty $z$ wszystkiego.

Jakoby mara-człowiek, wyzuty $z$ wszystkiego stoi Chrystus przed oczyma naszej duszy. Takim go widział św. Paweł, gdy pisał do Filipian (2, 7): Jakkolwiek Chrystus Jezus miał $w$ sobie postać Boża, nie uważał równości $z$ Bogiem za rzecz godna pożadania, lecz wyzut się $z$ wszystkiego przyjmujac postawe niewolnika. A będac teraz do ludzi podobnym, uczynit się niżsym (od innych) $i$ stat się postusznym aż do gotowości na śmierć, nawet na śmierć krzyżowa.

Tak Chrystus stał się ,niewolnikiem”, chciał umrzeć jak niewolnik, gdyż ukrzyżowanie było formą stracenia przeznaczoną dla niewolników (supplicium servile), by lud swój wybawié z niewoli Starego Zakonu a cały świat z niewoli grzechu i wszystkim przydzielić "wspaniała i zaszczytna wolność dzieci Bożych". (Rzym 8, 15).

\section{STACJA XI.}

Krótko, bardzo krótko, opisują ewangeliści chwilę najokrutniejszą, kiedy żołnierze przybijają Jezusa do Krzyża. Była godzina trzecia pisze św. Marek $(15,25)-i$ ukrzyżowali go. Brak w ewangeliach bliższych szczegółów, które sobie uzupełniamy na podstawie wiadomości historycznych opisujących stracenie przestępców przez ukrzyżowanie. Milczą o tym ewangeliści, gdyż wspomnienie momentu ukrzyżowania było dla nich, jak i dla wszystkich chrześcijan w owych czasach, zbyt bolesne i upokarzające. Jak zwyczaj nakazywa1, rzucono Chrystusa na drzewo krzyżowe i zaczęto przebijać dłonie i stopy. Krew zaczęła tryskać z ran i spływała na krzyż i na ziemię. Pomimo ogromnego bólu Jezus nie złorzeczy, nie żali się na nikogo, wie, że żołnierze spełniają tylko swój obowiązek, i dlatego właśnie za nich się modii, jak o tym wspomina św. Eukasz (23, 34): Ojcze, odpuść im, bo nie wiedza, co czynia! Za nich, za ludzi nie znających wiary $w$ jednego Boga, modli się Jezus i daje 
do zrozumienia, że Żydzi i poganie są mu równo bliscy, gdyż jest Zbawicielem wszystkich ludzi. Daje nam przykład, jak w życiu należy stosować jego upomnienie: Miłujcie nieprzyjaciót waszych, $i$ módlcie się za prześladowców waszych, abyście się stali (prawdziwymi) dziećmi Ojca waszego w niebiosach, gdyż On każe wschodzić słoncu nad dobrymi i złymi (Mat 5, 44).

Razi nas fakt, że Pan Jezus został ukrzyżowany razem z przestępcami, zdaje się nam, że chwila ukrzyżowania Zbawiciela została przez to zbeszczeszczona, ale taka była wyraźna wola Boga- Ojca i Pana Jezusa, gdyż miało się spełnić słowo Izajasza: do złoczyńców zostat (Mesjasz) zaliczony (Iz 53, 12 por. Łuk 22, 37). Nie dziwmy się temu. Przecież Pan Jezus szczycił się tym i cieszył z tego, że „̧o nazywano przyjacielem celników i grzeszników (Mat 11, 19). Wszak było zadaniem Syna Człowieczego odszukać i zbawić to, co zginęło (Mat. 18, 11).

Posłuchajmy, jak głęboko ujęła tę myśl księga Izajasza (53, 12):

Bo tak spodobato się Panu,

by go zniszczyć cierpieniem....

$i$ wśród zbrodniarzy został zaliczony

a on grzechy wielu wziat na siebie

za zbrodniarzy się modlit....

Nie tylko modlił się za nich, ale i za nich krew swą przelewał, aby im zapewnić zbawienie. W pierwotnej gminie chrześcijańskiej szczególnie czczono tajemniczą siłę krwi Chrystusowej wylanej na Golgocie, cześć ta rosła w Średniowieczu a obecnie znów odżyła, jak o tym świadczy świeżo wydana litania do Krwi Najdroższej. Krew sącząca się z ran Chrystusowych to krew naszego odkupienia, o której Pan Jezus powiedział przy ostatniej wieczerzy: ,To jest krew nowego przymierza wylana za wielu na odpuszczenie grzechów" (Mat 26, 28). Jej wartość i znaczenie zrozumiał dogłębnie św. Piotr, gdyż upomina wiernych (I list 1, 18): „wiedzcie, żeście nie za cenę rzeczy zniszczalnych, za cenę złota i srebra odkupieni zostali, lecz za cenę najwyższą, za cenę krwi Chrystusa, który na baranka bez braków i skaz przeznaczony został przed założeniem świata". A św. Paweł uzupełnia jego myśli zaznaczając, że Chrystus za cenę własnej krwi nabył Kościół Boży (Dz 20, 28).

Nie tyle woda chrztu świętego nas uczyniła chrześcijanami, ile krew Chrystusowa, która swej siły nadprzyrodzonej udzieliła wodzie by nas obmyła z wszelkich win i grzechów. Dlatego jaknajściślejsza jest łączność każdego chrześcijanina z krzyżem i krwią Chrystusa Pana. Każdy z nas powinien za św. Pawłem powtarzać: „Z Chrystusem jestem przybity do krzyża, już nie żyję, ale żyje we mnie Chrystus" (Gal 2, 19. 
Wyobraźmy sobie, jak .żołnierze podnoszą krzyż, do któreģo przybili Pana Jezusa. Między niebiem i ziemią zawisł Syn Bck̇y. Ręce jego rozłożone i wzniesione $\mathrm{ku}$ niebu a usta jego powtarzaja. za psalmistą $(40,2)$ „Podniesienie rąk moich jest moją ofiarą wreczorną". Bo już się ma ku wieczorowi i już. się kończy jedyna, prawdziwa liturgia, w czasie której Bóg Bogu składa ofiarę, w której. udział mistyczny bierze cała ludzkość żyjąca na ziemi wczoraj, dziś i jutro. Nie ,ite, missa est" woła Chrystus do nas z krzyża, lecz „,consummatum est”, dokonało się dzieło odkupienia, skończył się obrzęd ofiarny.

Posłuchajmy, jak świadek naoczny, św. Jan, opisuje ostatnie chwile Pana Jezusa $(19,28)$ : A Jezus wiedzac, $\dot{z} e$ już wszystko się spelnito, rzekt .....: pragne. Stato tam naczynie $z$ octem ' $i$ (żotnierze) gąbke napelniona octem wlożyli na oszczep $i$ podali mu do ust. I Jezus wzią ocet (do ust) i potem rzekt: dokonato się. I opuściwszy głowę wyzioną ducha. A św. Jana uzupełniają inni ewangeliści Mateusz pisze krótko: I wydat Jezus głośny krzyk i wyzioną ducha. Więcej zaś dowiadujemy się od św. Łukasza (23, 44): A była już prawie godzina szósta i ciemności nastały $w$ całym kraju az do godziny dziewiatej, gdyż słońce przestało świecić. I zawołał Jezus silnym glosem: Ojcze, w ręce twoje oddaie ducha mego, a rzekłszy to skonał. Inny jeszcze szczegół, a bardzo znamienny, przekazał nam św. Jan $(19,34)$ : I przyszli żołnierze do Jezusa, a widzac, $\dot{z} e$ już umart, nie połamali mu nóg, lecz jeden $z$ nich przebił włócznia jego bok a natychmiast wyszła krew $i$ woda.

W głębokim milczeniu zbliżamy się do Chrystusa umierajcego, bo tylko milczenie może uczcić wielkość tej chwili. Żadne słowo ludzkie, żaden obrzęd liturgiczny, żadne misterium poetyckie, nie jest w stanie, oddać całą treść najpotężniejszego dramatu, który się dokonał na Golgocie. Jedynie milczenie najgłębsze, milczenie ust i myśli, usposabia odpowiednio nasze dusze, by móc odczuć i przeżyć ponownie śmierć Syna Bożego, śmierć Boga ofiarującego się za człowieka! Milczenie nasze jest naśladownictwem milczenia i ciszy, jakie nastały po zgonie Chrystusa na wzgórzu golgockim. Umilkły głosy prześladowców i tłumu a rozlegały się jedynie łkania kobiet płaczących. Lecz nagle przerwał ciszę głos setnika, zawołał (Mk 15, 39): Naprawde, człowiek ten byt synem Bożym!

Niech okrzyk pogańskiego setnika także nam wiarę wzmacnia, wiarę w Chrystusa Boga i Zbawiciela, który umarł ,wydawszy głośny krzyk". Krzyk ten jest dla nas dowodem, że Chrystus nie umiera po trzech godzinach $\mathrm{z}$ wyczerpania fizycznego, lecz oddaje ducha w ręce Ojca niebieskiego w takim momencie, który sam sobie obrał na dokończenie aktu ofiarnego. Słyszał nad sobą niejako 
głos Boga-Ojca, przemawiającego doń słowami proroka (Iz 51, 22): Biorę już kielich $z$ ręki twojej, już pić nie będziesz $z$ kielicha mego rozgniewania.

Ale ostatni krzyk Chrystusa był równocześnie okrzykiem triumfu i zwycięstwa, podobnym do tego, ktỏry miał później ułożyć św. Poweł, wzorując się na proroku Ozeaszu (I Kor 15, 55):

Gdzie jest, o śmierci, zwycięsto twoje, gdzie jest, o śmierci, żadło twe?

Zniszczona jest śmierć na zawsze! (Iz 25, 8)

Niech widok krzyża jako symbolu zwycięstwa na chwilę przytłumi uczucia smutku i bólu, zwłaszcza gdy sobie uprzytomnimy, że miliony pokochały krzyż Chrystusowy, że cześć dla krzyża rośnie na ziemi z każdym wiekiem. Spełniła się przepowiednia wieszcza Bożego (Iz 53, 12), w której Jahwe mówi do Mesjasza: „Dlatego, że oddał na śmierć swe życie, dam mu w przydziale bardzo wielu, dam mu jako zdobycz rzesze ogromne".

Dziękujemy Bogu, że nas i nasz naród oddał jako zdobycz Ukrzyżowanemu!

\section{STACJA XIII.}

A gdy nastat wieczór - pisze św. Marek (15, 41) - przybyz Józef $z$ Arymatei, poważany członek Rady żydowskiej, który także oczekiwał królestwa Bożego, i śmiato udał się do Piłata $i$ poprosit o ciato Jezusowe, Piłat się zdziwit, że Jezus juz umart, i wydat ciało. A Józef poszedł $i$ zdjął jego ciało.

Jakież to dziwne i smutne! Nikt $z$ Apostołów nie podjął się tego obowiazku, uczynił to człowiek spoza ich grona. Czyż nie była słuszna przypowieść Chrystusowa o miłosiernym Samarytaninie? Ani kapłan ani lewita nie okazali miłosierdzia nad bratem zranionym, lecz uczynił to samarytanin, człowiek obcy, wyznawca religii schizmatyckiej! To samo powtórzyło się w chwili zabrania Pana Jezusa $\mathrm{i}$ w chwili jego śmierci, nawet w stosunku do jego osoby. Mógł Pan Jezus się skarżyć, jak Ijob sprawiedliwy: Moi bracia stoja z daleka, przyjaciele odsuwaja się ode mnie a znajomi zapominaja o mnie $(18,13)$, lub jak św. Paweł, który pisze w II liście do Tymoteusza $(4,16)$ : Nikt nie był przy mnie, wszyscy opuścili mnie.

Ale wytrwały przy nim niewiasty, wytrwał i św. Jan, gdyż głębokie uczucie przyjaźni i miłości łączyło go z Jezusem i Marią, spotẹgowane jeszcze przez słowa pożegnalne Chrystusa, z krzyża do niego skierowane a oddające mu Marię w opiekę. A smutek ich jest szczery i wielki, gdyż skazanie Chrystusa na śmierć tak ich przygnębiło, że myśl o jego zmartwychwstaniu żyła tylko w ich podświadomości i nie owładnęła ich duszy. Stoją obok Marii razem 
z Józefem z Arymatei, a może i z Nikodemem, i według słów proroka Zachariasza $(12,10)$,patrzą na tego, którego przebito, i płaczą płaczem, jak nad jedynakiem, i zawodzą, jak się zawodzi nad synem pierworodnym".

Stygnące ciało Chrystusa, zdjęte już z krzyża, kładą Jan i Józef na prześcieradle, by je przenieść do grobu. Kiedy ciało przez chwilę leży na ziemi, Matka Najświętsza - tak nam przypuszczać wolno krwawiące jeszcze stopy i ręce i głęboką ranę, zadaną Chrystusowi po śmierści w bok i serce, całuje z wielkim bólem w duszy i ust od ran oderwać nie może. Przecież to ostatni miecierzyński pocałunek, tak straszny i okrutny, tak pełen tragizmu. Naprawdę, „ogromny jak morze" (Lam 2, 13) jest ból matki opłakującej śmierć syna, straconego przez własnych braci! Czymże wobec tego był ból Hagary patrzącej na konanie Ismaela (Gen 21, 16), czym ból Jakuba po utracie Józefa (Gen 37, 34)? Wierzyła Maria, że jej syn był synem Bożym i jako taki istotą nieśmiertelną, lecz pod wpływem bólu i rozpaczy zapominała o wszystkim, co jej mówił Jezus, z czym jej się zwierzył w ich domu rodzinnym w Nazaret. Stąd wniosek, że miecz boleści naprawdę prezszył duszę Marii, że chwile pod krzyżem przeżyte to jej wielkie martyrium, które ja stawia na czele zastępu śẉiętych męczenników i nas uprawnia do oddawania jej czci jako ich królowej.

Św. Jan nie odstępuje Marii, gdyż Pan Jezus oddał ją na krzyżu pod jego opiekę. Głęboko zapisały się w jego duszy słowa konającego Mistrza: oto matka twoja. Obok niej kroczy, gdy przyjaciele przenoszą ciało Chrystusowe do grobowca w sąsiednim ogrodzie, kroczy bez słów, jak i milczy cały orszak pogrzebowy, składający się z kilku zaledwie osób, gdyż słowami nikt Marii pocieszyć nie potrafi.

I my także Matki Bożej Bolesnej pocieszyć nie potrafimy w jej smutku, który stale się odnawia, ilekroć widzi w niebiesiech, że grzechy i upadki nasze ponownie przybijają Chrystusa do krzyża a jej serce na nowo przeszywają mieczem boleści. $\mathrm{Z}$ wdziecznością jednak przyjmie Maria nasze modlitwy o nawrócenie braci słabych, grzesznych i niewiernych i oczekuje od nas szczerej obietnicy, że zrzucimy $z$ siebie starego czlowieka a przywdziejemy nowego, który na obraz Boga stworzony jest $w$ prawdziwej sprawiedliwości i świętości (Ef 5, 24).

\section{STACJA XIV.}

Uzupełniają się ewangeliści wzajemnie w opisywaniu grubu Pana Jezusa. Mateusz pisze $(27,59)$ : „Józef z Arymatei wziął ciało, owiną je w czyste prześcieradło i złożył w owym nowym grobie, który dawniej kazał wykuć sobie w skale! Więcej dowiadujemy się od św. Jana (19, 39), u którego czytamy: „Przybył Nikodem 
i przyniósł około sto funtów mieszanki mirry i aloesu. Wzięli ciało Jezusowe i owinęli je $\mathrm{w}$ prześcieradła zlane wonnymi olejkami.... A na miejscu gdzie go ukrzyżowano, był ogród a w ogrodzie nowy grobowiec, w którym jeszcze nikt nie był złożony. I tam pochowano Jezusa." Te same wiadomości przekazał nam św. Łukasz, lecz wspomina także o kobietach, które przybyły z Jezusem z Galilei. One towarzyszyły im $i$ patrzały na grób $i$ jak jego ciało składano $(23,55)$.

Nie mamy w ewangeliach żadnej wzmianki o tym, by i Matka Jezusowa stała przy grobie. Nie dziwmy się wcale, że jej tam nie było. Nie starczyło jej sił fizycznych, by odbyć krótką drogę do ogrodu Józefa. Wraz z św. Janem pozostała na miejscu najświętszym dla niej i dla świata, skropionym obficie krwią ofiarną jej Syna, przy ołtarzu, na którym On życie swe oddał za odkupienie świata a przy którym ona także swe cierpienia ofiarowywała Bogu-Ojcu jako duchowe całopalenie. Wystarcza jej, że widzi w mroku wieczornym cienie przyjaciół i przyjaciółek składających ciało najdroższe w zimnym skalnym grobie, wystarcza jej myśl, że Jezus ma koło siebie osoby całą duszą mu oddane.

Przy Maryii stoi św. Jan. Kilkadziesiąt kroków tylko dzieli go od grobu, Trwa w głębokim zadumieniu. Pomimo smutku snuje myśli teologiczne i w duchu umieszcza nad grobem jako napis słowa Chrystusowe, wypowiedziane kiedyś w nocy do Nikodema: Albowiem tak Bóg umiłowat świat, ̇̇e Syna swego jednorodzonego wydat na śmierć, aby każdy, kto weń uwierzy, nie zginą a miat życie wieczne. A dalej wpatruje się w ogród otaczający grobowiec. Widzi bujną zieleń drzew rozwijających się nagle w porze wiosennej, widzi wielobarwne piękno kwiatów właśnie rozkwitających i wysyłających teraz pod wieczór ostrą a miłą woń. Zdaje mi się, że przyroda w ten sposób zielenią i kwiatami czci chwilę pogrzebu. Zabrakło ludzi a nie brakło zieleni i kwiatów!

Przyłączmy się do hołdu, jaki przyroda składa Chrystusowi leżącemu w grobie, a równocześnie złączmy się z chórami anielskimi, które według Objawienia św. Jana $(5,11)$ śpiewają hymn czci i dziękczynienia: „Godzień jest Baranek, który został zabity, by otrzymał potęgę i (łask) bogactwo i mądrość i moc i czešć i chwałę i uwielbienie"!

Zdawać by się mogło, że z chwilą, złożenia ciała w grobie historia Jezusa Nazareńskiego się skończyła. Tak naprawdę zdawać się mogło nawet jeszcze przez następne dwa dni. Lecz Pan Jezus miał z grobu zmartwychwstać i $z$ grobowca miał się zrodzic Kościół Chrystusowy. Oto właściwie na opoce, w której wyḳuty był grób, zbudowany jest Kościół, którego bramy podziemia, bramy piekła i śmierci, nie zwyciężą, gdyż Kościół zbudowany jest 
i oparty na fakcie Zmartwychwstania, które miało miejsce w grobowcu Józefa z Arymatei.

Z grobu Jezus nas pociesza i woła na cały świat: Jam zmartwychwstanie i życie! (Jan 11, 25).

\section{Z a kończenie}

Śpiew pieśni: „Wisi na krzyżu” (opartej na tekstach biblijnych). Benedictio Sanctissimi.

Kraków

Ks. ALEKSY KLAWEK 